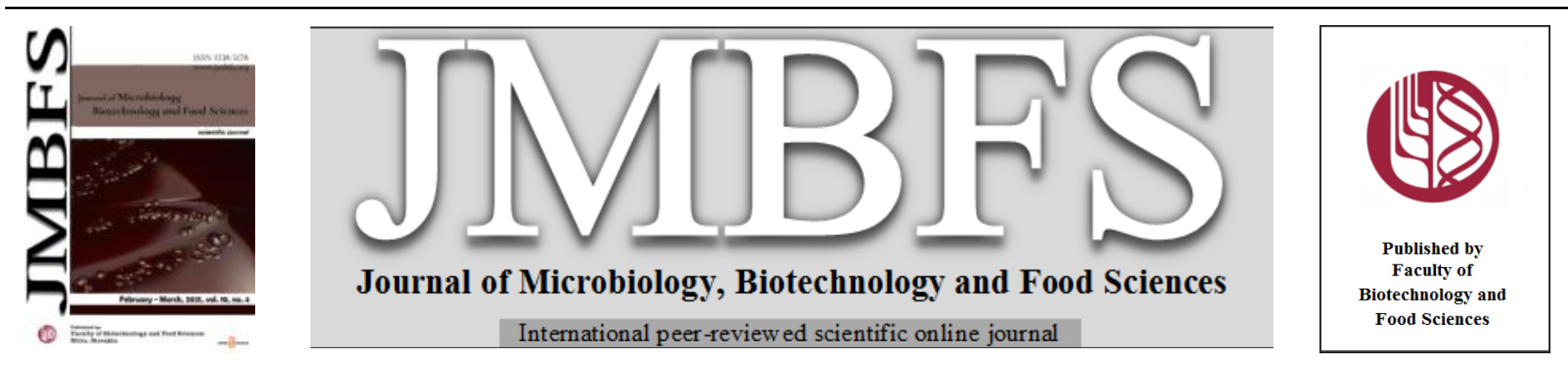

\title{
RESEARCH AND DEVELOPMENT OF TECHNOLOGY FOR PRODUCTION OF CANNED FOOD USING ENZYME PREPARATION OF ANIMAL ORIGIN
}

\author{
Aleksandr Lukin *1, Gulshod Khamraeva ${ }^{2}$, Natalya Zhuravleva ${ }^{2}$
}

\begin{abstract}
Address(es):
${ }^{1}$ Federal State Autonomous Educational Institution of Higher Education "South Ural State University (national research university)", Department of Higher School of Food and Biotechnology, 454080 Chelyabinsk, Russia.

${ }^{2}$ Federal State Autonomous Educational Institution of Higher Education "South Ural State University (national research university)", Institute of Sport, Tourism and Service, 454080 Chelyabinsk, Russia.
\end{abstract}

*Corresponding author: lukin3415@gmail.com

doi: 10.15414/jmbfs.2021.10.4.577-580

\section{ARTICLE INFO}

Received 13. 3. 2020

Revised 1. 10. 2020

Accepted 2. 10. 2020

Published 1. 2. 2021

Short communication open $\partial_{\text {ACCESS }}$

\section{ABSTRACT}

The study aims to see into the possibility of using an enzyme preparation of animal origin in canned food production technology. The technology and formula for the production of canned "Tomato and Beef Sauce" was developed. Beef of the second grade and the enzyme preparation Protepsin were used as raw materials. The effect of Protepsin on the functional and technological properties of the second grade beef was studied. The introduction of Protepsin into the meat system increased the water-binding and water-holding capacity, as well as the hydration of proteins due to the partial hydrolysis of proteins, including connective tissue, which led to an increase in functional groups and loosening of the protein structure, an increase in the immobilized moisture in meat and the penetration degree. The choice of a thickening agent in production technology for canned "Tomato and Beef Sauce" was also justified.

Keywords: second grade beef, enzyme preparation, canned food, production technology, food biotechnology

\section{INTRODUCTION}

Enzymes are used in various industries, which is explained by well-known advantages of biocatalytic processes, namely high speed of reactions, their mild course, selectivity and specificity of action on various substrates, low consumption, the possibility of bringing them into widespread use owing to good adaptability to traditional technologies, and so on (Ashei et al., 2006; Rivier and Sadoc, 2007; Tavano et al., 2018).

Various enzyme preparations of animal, plant and microbial origin are widely presented on the world market. At the same time, herbal and, more so, microbial preparations, tend to require deeper purification (Dransfield, 1994). The technological regimes of food raw materials at the final stages of production do not always ensure their complete inactivation, which poses food safety issues. In this regard, preparations of animal origin are becoming a better choice for food and other technologies not involving removal of enzymes. They are considered the most physiological, their properties and conditions of biocatalytic processes being identical to digestive enzymes and cathepsins of animal muscle tissue (Neklyudov and Ivankin, 2007; Purslow, 2005).

Protepsin is a new enzyme preparation of animal origin that has recently appeared on the domestic market of biologically active preparations.

The preparation is obtained by maceration of animal endocrine raw materials and subsequent purification, concentration, separation, and freeze-drying of the enzyme complex. Proteolytic activity (PA) of Protepsin begins at 50 units/g at $\mathrm{pH}$ 5.5 (Margander, 1995).

The continuous growth of production and consumption of meat products in our country makes it necessary to search for new ways to improve the technical and economic efficiency of production, as well as the product quality. The intensification of technological processes plays a large part in the successful solution of these problems. In particular, it is so with the use of enzyme preparations for meat processing (Ghaffari-Moghaddam et al., 2014).

Thus, being a relatively new technological method from a practical point of view, processing of meat with enzymes, in theoretical terms, is based on traditional biochemical processes occurring in meat and other protein-containing products at various stages of their production. Hydrolytic processes with the help of enzyme preparations take place much faster and more intense, which allows to boost the process (Morgan et al., 1993).

According to statistics, more than $60 \%$ of meat in our country goes to the meat processing enterprises with defects caused by intravital stresses that animals suffer from due to poor ecology, violations of the technology of keeping, poorquality feeding (Fayvishevsky, 2013). The meat of such animals is quite tough and requires additional processing. Currently, the increased toughness of meat is eliminated by an additional operation of massaging, which takes a lot of time. The use of Protepsin can significantly reduce the time of massaging, soften the raw materials, giving the meat additional moisture-holding capacity and the desired flavoring. At the same time, it increases the digestibility of finished products, and, consequently, their bioavailability (Arihara, 2006).

Histochemical studies have shown that when meat pieces are treated with an enzyme solution, the enzyme gets in the uniform contact with the main structural elements of muscle tissue throughout the meat (Mandl, 2000). It allows to achieve maximum softening of the meat with a minimum consumption of the enzyme (from $0.005 \%$ to $0.05 \%$ ), and the presence of salt increases the softening effect of the enzyme. Another reason why enzymatic processing of meat is of great interest is quite high cost of meat, while the amount of enzymes required for the softening is small (Kuzelov et al., 2002).

The differences noted during frying of fermented and control samples of meat are explained by the intense action of enzymes on the intramuscular connective tissue, which decreases reduction of the length of collagen fibers at the time of denaturation and, as a result, pieces are deformed less and less water is released from the meat (Spohner, et al., 2015). Significant destruction of collagen in fermented meat causes not only a decrease in the mechanical strength of the connective tissue layers, but also influences the relative increase in the strength of water bound in the meat.

The most promising enzymes are those of animal origin in the meat industry (Wouters, et al., 2016). The introduction of Protepsin into the meat system improves water-binding capacity and hydration of protein due to the interaction with the active centers of enzymes. The structure of protein is loosened, while meat immobilized moisture and the degree of penetration increases. With Protepsin, the weight loss of the meat system during heat treatment is reduced. Protepsin causes small but clear changes in the structure of collagen. The main part of the collagen molecule is absolutely resistant to Protepsin. At first, Protepsin acts on the accompanying substances, and later on the terminal end of the collagen molecule. A longer exposure can cause disaggregation of fibrillar structures and the destruction of intramolecular crosslinks, promoting the cleavage of the terminal ends of collagen molecules not part of triple helices (while the collagen helix structure is preserved). 
Protepsin affects intermolecular bonds of collagen. Collagen breaks down to monomeric tropocollagen molecules, causing insoluble collagen to partially transform into a soluble state. The advantage of Protepsin is the fact that it does not get rapidly inactivated in a substrate with an increased $\mathrm{pH}$. Its complete inactivation takes place within 15 minutes at $70{ }^{\circ} \mathrm{C}$. Protepsin does not adversely affect the organoleptic characteristics of the finished product, contributing to the formation of a more pronounced taste and smell (Antipova and Gorbunkov, 2016)

\section{MATERIAL AND METHODS}

- Protepsin - enzyme preparation with standard proteolytic activity of 100 units/g produced by ZAO Zavod Endokrinnykh Fermentov, Rzhavki, Solnechnogorsky district, Moscow region;

- beef, grade 2;

- thickeners in different concentrations;

- formula of canned «Tomato and Beef Sauce».

Functional and technological properties (water-binding capacity (WBC) and water-holding capacity (WHC)) of raw meat were determined as recommended (Skurikhin and Tutelyan, 1998). The method of Grau and Hamm in the modification of V.P. Volovinskon and B.I. Kelman was used to evaluate waterbinding capacity (Skurikhin and Tutelyan, 1998).

The stability of the emulsion was determined by centrifugation in test tubes and the subsequent calculation of the amount of the moisture separated from the emulsion.

Organoleptic evaluation was carried out in accordance with GOST 32125-2013 «Canned meat in pieces. Stewed meat. Specifications».

To obtain high-quality product with good organoleptic characteristics, the following ingredients are proposed for "Tomato and Beef Sauce" formula: beef of the 2nd grade, bone broth, carrots, onions, tomato paste, dried green basil and parsley, ground black pepper.

The formula is presented in Table 1.

The ratio of the solid part (beef, onions, carrots) and the liquid part (bone broth) is 30:70. This ratio allows to obtain the required consistency of canned "Tomato and Beef Sauce", which should be stable, microbiologically stable in particular, with minimal loss of aroma and taste during storage.

Table 1 Formula of Canned «Tomato and Beef Sauce»

\begin{tabular}{lc}
\hline Raw Material & $\begin{array}{c}\text { Weight, kg per 100 } \\
\text { kg }\end{array}$ \\
\hline $\begin{array}{l}\text { Trimmed beef, grade 2, treated with Protepsin } \\
\text { enzyme preparation }\end{array}$ & 15 \\
\hline Bone broth & 59 \\
\hline Carrots & 7 \\
\hline Onions & 7 \\
\hline Tomato paste & 6 \\
\hline Thickener - 3\% starch & 3 \\
\hline Vegetable oil & 3 \\
\hline $\begin{array}{l}\text { Mixture of preservatives (benzoic acid and sodium } \\
\text { benzoate in a ratio of 1:1) }\end{array}$ & 0.2 \\
\hline Table salt & 1.5 \\
\hline Ground black pepper & 0.25 \\
\hline Basil & 0.5 \\
\hline Parsley & 0.3 \\
\hline
\end{tabular}

All measurements were carried out in three replications. Statistical analysis was performed using Microsoft Excel XP and Statistica 8.0 software package. The statistical error of the data did not exceed 5\% (at 95\% confidence level).

\section{RESULTS AND DISCUSSION}

Development of Production Technology of Canned «Tomato and Beef Sauce»

Frozen beef is defrosted, washed with tap water, stripped, deboned, trimmed, meat of the 2nd grade is selected. Then it is chopped into small pieces (Bhaskar et al., 2007).

The preparation (Protepsin) is dissolved in clean drinking water at $35-36^{\circ} \mathrm{C}$ in the amount of $1 \mathrm{~g}$ of powder per $100 \mathrm{ml}$ of water. The solution is stirred and left to stand for 15-30 minutes. $100 \mathrm{~kg}$ of pre-chopped meat raw materials are mixed in a mixer with 1 liter of Protepsin solution and 5 liters of water for 1-2 minutes, then table salt is added and mixed until uniform. The raw materials are allowed to stand for 2-12 hours.

After the process of salting, the ground meat raw materials are fried in a pan on the electric stove with vegetable oil at $140{ }^{\circ} \mathrm{C}$ for $5-7$ minutes. Beef bones left after deboning are washed with tap water at $15-20^{\circ} \mathrm{C}$, placed in an enameled pan, poured with water in a ratio of 1:2 and cooked on the electric stove for 2-3 hours at $95-98^{\circ} \mathrm{C}$. The broth is passed through a gauze sieve to clean of small bones and pieces of meat.

Fresh onions are washed and cleaned manually, then ground in a grinder with holes of 5-6 mm in diameter. Carrots are washed, peeled, washed again and ground in a grinder with holes of 5-6 $\mathrm{mm}$ in diameter. Ground vegetables are sautéed in a frying pan on the electric stove at $120-125^{\circ} \mathrm{C}$ for $3-5$ minutes with vegetable oil in an amount of $5-20 \%$ by weight of raw vegetables.

Cooked broth, fried meat and sauteed vegetables are placed in an enameled pan, where they are cooked being constantly stirred for 20 minutes at $75-85^{\circ} \mathrm{C} .5$ minutes before the end of the process, salt, spices, thickener (3\% starch), tomato paste and a mixture of food preservatives (benzoic acid and sodium benzoate in a ratio of 1:1) are added. Glass jars are washed, scalded, rinsed and dryed.

Canned "Tomato and Beef Sauce" is portioned in prepared glass containers while hot, and then hermetically sealed with metal lids. The finished product is cooled to $20-25^{\circ} \mathrm{C}$, and then stored in a refrigerator at $3-5^{\circ} \mathrm{C}$.

The Rationale for Thickener Choice in Production Technology of Canned «Tomato and Beef Sauce»

The optimal concentration of the thickener was chosen basing on technological and organoleptic properties. According to the research, animal protein Polisomin $\mathrm{F}$, sodium caseinate, wheat and rye fiber in the specified concentrations did not exhibit the properties of a thickening agent, so 8 meat sauce samples were selected for further studies: with potato starch (2 and 3\% concentration), carrageenan ( 0.3 and $0.5 \%$ ), soy flour (5 and $7 \%$ ), and wheat flour (5 and $7 \%$ ) (Dickinson, 2012)

The results of determining the emulsion stability of selected samples of meat sauce are presented in Table 2 .

According to the obtained results, the emulsion had the greatest stability when starch $(3 \%)$, carrageenan $(0.5 \%)$, and soy flour $(7 \%)$ were used as a thickener.

Table 2 Effect of thickeners on the stability of emulsion from beef

\begin{tabular}{lcccc}
\hline Thickener & $\begin{array}{c}\text { Concentration of thickener, } \\
\text { \%, by weight of the product }\end{array}$ & $\begin{array}{c}\text { Volume of emulsion taken } \\
\text { for centrifugation, } \mathbf{c m}^{\mathbf{3}}\end{array}$ & $\begin{array}{c}\text { Volume of intact part } \\
\text { of emulsion, } \mathbf{~ c m}^{\mathbf{3}}\end{array}$ & Stability, \% \\
\hline Starch & 2 & 8 & 6.1 & $76.3 \pm 0.65$ \\
\hline Starch & 3 & 8 & 6.6 & $82.5 \pm 0.43$ \\
\hline Carrageenan & 0.3 & 8 & 6 & $75.0 \pm 0.81$ \\
\hline Carrageenan & 0.5 & 9 & 7.2 & $80.0 \pm 0.12$ \\
\hline Wheat flour & 5 & 7 & 4.6 & $65.7 \pm 0.18$ \\
\hline Wheat flour & 7 & 8 & 6.1 & $76.3 \pm 0.33$ \\
\hline Soy flour & 5 & 8 & 6.6 & $82.5 \pm 0.59$ \\
\hline Soy flour & 7 & 9 & 7.8 & $86.7 \pm 0.62$ \\
\hline
\end{tabular}

Study of Functional and Technological Properties of 2nd Grade Beef Treated with Protepsin Enzyme Preparation

The functional and technological properties (FTP) of the 2nd grade beef were studied in laboratory during the process of salting without (in case of the contro sample) and with the enzyme preparation (test sample). The findings are presented in Figures 1 and 2 . 


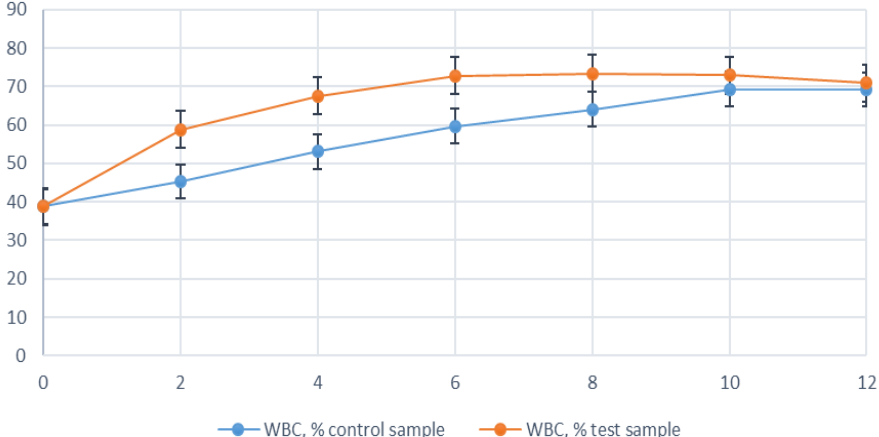

Figure 1 Change in $\mathrm{WBC}$ of 2nd Grade Beef during Salting without and with Enzyme Preparation

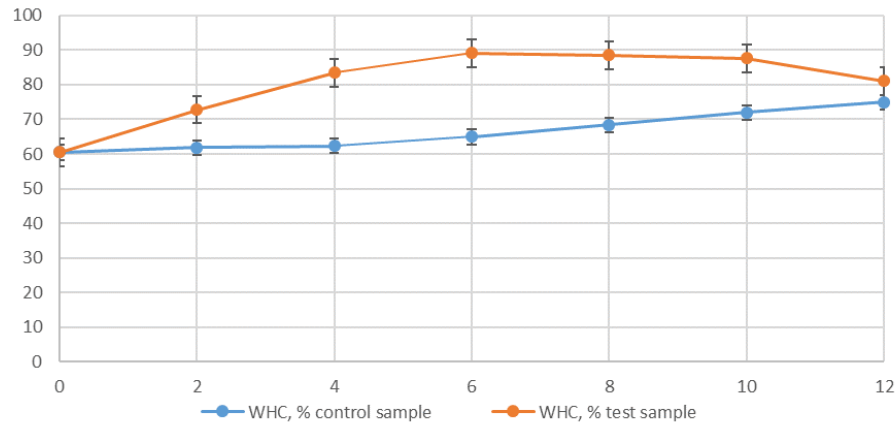

Figure 2 Change in WHC of 2nd Grade Beef during Salting without and with Enzyme Preparation

It was established that the maximum WHC in the test sample is observed during exposure for 6-8 hours (on average - $73.17 \pm 0.16 \%$ ), which is associated with the maximum rate of the effect of enzyme preparations on proteins of beef of the 2nd grade and the connective tissue itself. In this case, loosening of the connective tissue was noted, which is possibly associated with a change in the secondary and tertiary structure of the collagen of the connective tissue.

The exposure time of the control sample increases to 12 hours, and such meat has a low WBC value of $69.39 \pm 0.22 \%$, which will subsequently lead to a decrease in the yield of the finished product and a decrease in its organoleptic characteristics. The WHC also reaches its maximum when the test sample undergoes the prosess of salting for 6-8 hours (on average - $89.30 \pm 0.09 \%$ ).

\section{Organoleptic Evaluation of Canned «Tomato and Beef Sauce»}

Such organoleptic indicators as smell, taste, appearance, meat texture, and broth appearance were evaluated.

Figure 3 shows the results of the organoleptic evaluation.

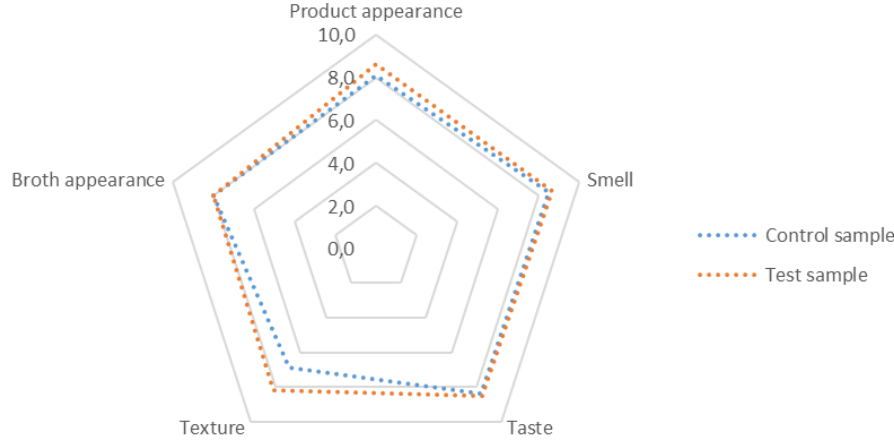

Figure 3 Organoleptic Evaluation of Canned «Tomato and Beef Sauce»

The control sample had rather a pleasant meat smell with distinct aroma of spices. The meat was cut into small pieces, meat fibers were quite pronounced After heating, the smell became more intense, pleasant, the aroma of spices became more pronounced. The broth was red, thin, salty, with pronounced meaty taste. The texture of meat was tough, the taste was distinctly salty. The obtained results were fully consistent with the results of the tasting evaluation, during which the sample had scored 7.9 points and had been classified as good quality.

The test sample had a very pleasant, intensely meaty, smell with light notes of spices. The pieces of meat were whole, fibrous, without veins, the texture was very juicy. The broth had a pleasant pronounced meat smell and was red, nontransparent, and thin. The obtained results were fully consistent with the results of the tasting evaluation, during which the test sample had scored 8.4 points and had been classified as very good quality.

The control sample had rather a pleasant meat smell with distinct aroma of spices. The meat was cut into small pieces, meat fibers were quite pronounced. After heating, the smell became more intense, pleasant, the aroma of spices became more pronounced. The broth was red, thin, salty, with pronounced meaty taste. The texture of meat was tough, the taste was distinctly salty. The obtained results were fully consistent with the results of the tasting evaluation, during which the sample had scored 7.9 points and had been classified as good quality. The test sample had a very pleasant, intensely meaty, smell with light notes of spices. The pieces of meat were whole, fibrous, without veins, the texture was very juicy. The broth had a pleasant pronounced meat smell and was red, nontransparent, and thin. The obtained results were fully consistent with the results of the tasting evaluation, during which the test sample had scored 8.4 points and had been classified as very good quality.

\section{CONCLUSION}

In the course of experimental tests, a technology for the production of canned "Tomato and Beef Sauce" was developed. The method involved preparing the specified ingredients. Pre-chopped meat raw material was treated with a solution of Protepsin in 5:1 ratio of water to Protepsin. The next steps involved frying meat raw materials, preparing bone raw materials, cooking broth, preparing and sautéing vegetables, mixing and pasteurizing all components, sealing and sterilization

The introduction of Protepsin enzyme preparation into the meat system increased WBC, WHC and protein hydration due to partial hydrolysis of proteins, including connective tissue, which led to an increase in functional groups and loosening of the protein structure, an increase in the immobilized moisture in meat and the degree of penetration. In addition, the use of Protepsin significantly reduced the time of salting raw materials and reduced the loss of meat mass during heat treatment due to the synergy of its own muscle tissue enzymes.

The developed technology increased organoleptic characteristics of canned food, intensified the production process allowing to use low-grade meat raw materials in the production.

Acknowledgments: The work was supported by Act 211 of the Government of the Russian Federation, contract № 02.A03.21.0011.

\section{REFERENCES}

Antipova, L.V., Gorbunkov, M.V. (2016). Physical-chemical and biocatalytic properties of a proteolytic complex of the preparation "Protepsin". Proceedings of the Voronezh State University of Engineering Technologies, 1, 89-95. http://dx.doi.org/10.20914/2310-1202-2016-1-89-95

Arihara, K. (2006). Strategies for designing novel functional meat products. Meat Science, 74, 219-229. http://dx.doi.org/10.1016/j.meatsci.2006.04.028

Ashei, I., Sorensen, T. L., Nilsen, P. M. (2006). Effects of Papain and a Microbial Enzyme on Meat Proteins and Beef Tenderness. Journal of Food Science, 21382142. http://dx.doi.org/10.1111/j.1365-2621.2002.tb09516.x

Bhaskar, N., Modi, V. K., Govindaraju, K., Radha, C., Lalitha, R. G. (2007). Utilization of meat industry by products: protein hydrolysate from sheep visceral $\begin{array}{llll}\text { mass. } & \text { Bioresource } & \text { Technology, } & \text { 98(2), }\end{array}$ http://dx.doi.org/10.1016/j.biortech.2005.12.017

Dickinson, E. (2012). Stabilising emulsion-based colloidal structures with mixed food ingredients. Journal of the Science of Food and Agriculture, 93(4), 710721. http://dx.doi.org/10.1002/jsfa.6013

Dransfield, E. (1994). Optimization of tenderization, ageing and tenderness. Meat Science, 36, 105-121. http://dx.doi.org/10.1016/0309-1740(94)90037-X

Fayvishevsky, M.L. (2013). Low-waste technologies at meat-packing plants. Moscow: Kolos, $207 \mathrm{p}$.

Ghaffari-Moghaddam, M., Eslahi, H., Omay, D., Zakipour-Rahimabadi, E (2014). Industrial applications of enzymes. Review Journal of Chemistry, 4(4), 341-361. http://dx.doi.org/10.1134/S2079978014040037

Kuzelov, A., Vasilev, K., Velkova, K. (2002). Influence of microbial enzyme preparation upon structural and mechanical properties of meat raw materials from big ruminants. Food Tasting Industry, 4, 13-14.

Mandl, I. (2000). Collagenases and Elastases. Advances in Enzymology. Interscience Publishers, London, p. 123-125.

Margander, K. (1995). Collagen proteins as aids to improve the technological and sensory characteristics of meat products and ready meals. Fleicshwirtschaft, 75(11), 1286-1287.

Morgan, J.B., Wheeler, T.L., Kohmaraie, M., Savel, J.W., Crouse, J.D. (1993) Meat tenderness and the Calpain Proteolytic System in Longissimus Muscle of Young Bulls and Steers. Journal of Animal Science, 71(6), 1471-1476. http://dx.doi.org/10.2527/1993.7161471x

Neklyudov, A.D., Ivankin, A.N. (2007). Collagen: production, properties and application. (Moscow: Publishing house MGUL). p 336. 
Purslow, P.P. (2005). Intramuscular connective tissue and role in meat usality. Meat Science, 70, 435-447. http://dx.doi.org/10.1016/j.meatsci.2004.06.028

Rivier, N., Sadoc, J.F. (2007). Topology in Molecular Biology. Springer Berlin Heidelberg, 147-162.

Skurikhin, I.M., Tutelyan, V.A. (1998). A guide to the methods of analyzing food quality and safety. Moscow, Brandes, Medicine, pp. 213-221.

Spohner, S.C., Müller, H., Quitmann, H., Czermak, P. (2015). Expression of enzymes for the usage in food and feed industry with Pichia pastoris. Journal of biotechnology, 202, 118-134. http://dx.doi.org/10.1016/j.jbiotec.2015.01.027

Tavano, O.L., Berenguer-Murcia, A., Secundo, F., Fernandez-Lafuente, R (2018). Biotechnological applications of proteases in food technology. Comprehensive Reviews in Food Science and Food Safety, 17, 412-436. http://dx.doi.org/10.1111/1541-4337.12326

Wouters, A. G., Rombouts, I., Fierens, E., Brijs, K., Delcour, J. A. (2016)

Relevance of the functional properties of enzymatic plant protein hydrolyzate in food systems. Comprehensive Reviews in Food Science and Food Safety, 15, 786-800. http://dx.doi.org/10.1111/1541-4337.12209. 